\title{
Developmental mechanisms directing early anterior forebrain specification in vertebrates
}

\author{
Cynthia Lilian Andoniadou • \\ Juan Pedro Martinez-Barbera
}

Received: 6 November 2012 / Revised: 10 January 2013 / Accepted: 17 January 2013 / Published online: 9 February 2013

(C) The Author(s) 2013. This article is published with open access at Springerlink.com

\begin{abstract}
Research from the last 15 years has provided a working model for how the anterior forebrain is induced and specified during the early stages of embryogenesis. This model relies on three basic processes: (1) induction of the neural plate from naive ectoderm requires the inhibition of BMP/TGF $\beta$ signaling; (2) induced neural tissue initially acquires an anterior identity (i.e., anterior forebrain); (3) maintenance and expansion of the anterior forebrain depends on the antagonism of posteriorizing signals that would otherwise transform this tissue into posterior neural fates. In this review, we present a historical perspective examining some of the significant experiments that have helped to delineate this molecular model. In addition, we discuss the function of the relevant tissues that act prior to and during gastrulation to ensure proper anterior forebrain formation. Finally, we elaborate data, mainly obtained from the analyses of mouse mutants, supporting a role for transcriptional repressors in the regulation of cell competence within the anterior forebrain. The aim of this review is to provide the reader with a general overview of the signals as well as the signaling centers that control the development of the anterior neural plate.
\end{abstract}

Keywords Anterior forebrain - Neural induction - AVE . Hesx $1 \cdot$ Six $3 \cdot$ Tcf3

C. L. Andoniadou · J. P. Martinez-Barbera $(\square)$

Birth Defects Research Centre, UCL Institute of Child Health, 30 Guilford Street, London WC1N 1EH, UK

e-mail: j.martinez-barbera@ucl.ac.uk

\section{Introduction}

The overall anatomical structure of the mature vertebrate brain has been highly preserved throughout evolution, although the degree of development of particular domains can vary enormously between species. From fish to mammals, the brain can be divided into three main areas according to their position along the antero-posterior axis: the fore-, mid-, and hindbrain. The anterior forebrain includes the telencephalon (cortex, hippocampus, and basal ganglia), hypothalamus, prethalamus as well as the eyes and visual tracts (optic chiasm). The posterior forebrain comprises the thalamus, epithalamus, and pretectum [59, 128, 129]. The entire brain has a common origin during early embryonic development in a single-layered pseudostratified epithelium called the neural plate (NP). The NP becomes molecularly distinct to surface ectoderm (destined to form the skin) soon after gastrulation when neural induction takes place. Subsequently, it is divided into domains along the anteroposterior and medio-lateral axes characterized by specific gene expression patterns, which will eventually give rise to brain structures at later stages of development [121, 130]. Using embryological techniques such as single cell labeling and cell transplantations or genetic approaches (i.e., genetic tracing using mouse lines expressing Cre recombinase), the origins of the distinct components of the mature brain have been mapped in the early NP $[25,27-29,63,123,159]$. Such studies have also demonstrated a remarkable degree of conservation between species at early embryonic stages, despite the considerable differences in the shape and size of their mature brain structures.

The focus of this article is to revise the major findings that have contributed in the generation of a model of how the forebrain is formed during the early stages of development and in particular, the mechanisms underlying anterior forebrain 
formation. We have attempted to provide a historical perspective of the milestones that provided the foundations to this model and to link these with more recent discoveries. We aim to discuss findings obtained from studies in different animal models, often first describing the results obtained from the initial experiments regardless of the species and commenting on the degree of conservation in other experimental models. We will discuss the relevance of essential signaling centers as well as critical signals involved in the process of anterior forebrain formation, paying special attention to the WNT/ $\beta$-catenin pathway. To learn about the numerous intrinsic factors that are also essential for normal anterior forebrain development we refer the readers to other published review articles $[9,59,76]$.

\section{Neural induction and antero-posterior axis formation: a historical perspective}

The study of anterior NP (ANP) specification, neural induction, and antero-posterior (AP) axis formation are intimately linked. Experiments by Hans Spemann and Hilde Mangold [134] demonstrated that an entire ectopic axis extending from the forebrain to the spinal cord could be induced in a host newt embryo by a group of cells from the dorsal blastopore lip (Fig. 1). This ectopic axis was complete in that a neural tube encompassing forebrain (i.e., ectopic eyes) and spinal cord had developed over an ectopic notochord and was flanked by somites. Newt species with white or dark pigments were used to discriminate the contribution of the host and the donor tissues to the ectopic axis. The ectopic neural axis was comprised of mostly host cells, demonstrating that the donor cells have inducing properties and was named "the organizer". Moreover, the abilities of the organizer were stage dependent, as dorsal blastopore lip cells from younger embryos were capable of inducing an entire ectopic neural axis (brain and spinal cord), but older ones gave rise to ectopic axes lacking the eyes. This gave support to a model whereby the activities of the organizer can be divided into the "head" and "trunk" organizers, with early activities inducing anterior neural identity and late activities only posterior neural fates. This concept, however, was challenged many years later by another developmental biologist, Pieter Nieuwkoop [106], who carried out an ingenious transplantation experiment using the urodele embryo. He inserted pieces of naive ectoderm along the rostro-caudal neural axis of the host embryo and later analyzed the presence of anterior (forebrain) or posterior neural structures. He observed that forebrain structures developed at the distal tip of the flap and posterior structures at the base, matching the neural identity of the level at which it was initially inserted in the host. This led him to postulate the "induction-transformation" model, whereby neural tissue is initially induced with anterior character and subsequently caudalized by signals from the organizer with transforming activity.

Some basic principles derived from these experiments have survived to date. Structures with similar activities to the amphibian organizer were identified in other vertebrate species including chick (Hensen's node), zebrafish (embryonic shield), and mouse (node). In these, the transplantation of the organizer led to similar results to those in amphibians $[124,138,153]$. However, it came as a surprise that transplantation of the mouse node gave rise to an incomplete axis lacking the anterior forebrain $[10,145]$. The possibility existed that the difficulty of such transplantations in the small mouse embryo may affect the results and so, the inability of inducing a full axis may be a "technical flaw". Even in Xenopus, where these experiments are easier due to the larger embryo size, only a small proportion develop a full neural axis upon dorsal blastopore lip transplantation. An alternative explanation may be that the transplanting node only contained the posterior inducing activity, as does

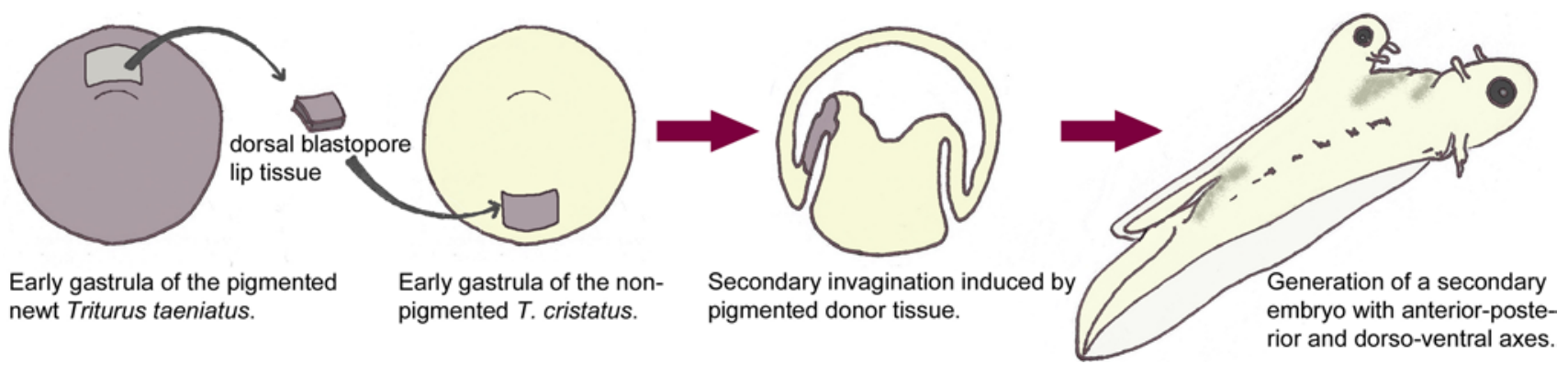

Fig. 1 Dorsal blastopore lip tissue of the early gastrula displays organizing activity. Excision of dorsal blastopore lip tissue from the pigmented newt Triturus taeniatus and transplantation in the region of presumptive ventral epidermis in a non-pigmented Triturus cristatus early gastrula. The donor tissue induces a secondary invagination in the host embryo and exerts organizing activity to surrounding host tissues. A secondary embryo forms where the donor tissue contributes mainly to notochord and prechordal mesoderm structures and re-organizes the normally ventral surrounding host tissues, which are dorsalized into neural tube and mesoderm (adapted from Gilbert, Developmental Biology) 
the late or trunk organizer of the amphibian embryo. However, even the transplantation of cells from the "tip of the primitive streak" at early streak stages (early gastrula organizer, EGO), which contains precursors of the node, failed to induce a full axis [145].

The answer to this discrepancy observed in the mouse was simpler: the node/EGO did not contain all the information required to induce an entire neural axis because the anterior visceral endoderm (AVE) was necessary for anterior neural tissue to develop (Fig. 2) [146]. There have been numerous reviews on the subject, so we will just summarize some major findings that have provided support to this idea [11, 12, 94, 135, 143]. The AVE was found to contain a group of cells, which express several genes relevant for head formation (i.e., Otx2, Lhx1, Foxa2, Cerl, Leftyl, and Dkkl among others) and was patterned prior to any signs of primitive streak formation. Moreover, genetic evidence demonstrated the requirement of several of these genes specifically in the AVE for normal antero-posterior axis formation and anterior forebrain development $[1,38$, $70,71,101,114,117,127,151,161]$. This was in addition to a critical role for some of these genes within the anterior neural plate (e.g., Otx2) [1, 17, 117]. Tissues equivalent to the mouse AVE, according to their location and molecular expression patterns, exist in embryos of chick (hypoblast), zebrafish (dorsal syncytial layer), and Xenopus (yolky cells of the vegetal pole), suggesting a conserved role in the vertebrate embryo [58, 65, 136]. Currently, it is broadly accepted that the AVE plays a critical role in the establishment of the AP axis and during anterior neural plate induction [86, 118, 157]. However, the formation of the anterior neural plate does not exclusively rely on AVE activities and there must be cooperation with other signaling centers such as the gastrula organizers and axial mesendoderm underlying the developing anterior neural plate. As proposed by Nieuwkoop, the synergism of these signaling centers aims to protect the anterior region of the epiblast from posteriorizing signals, which would otherwise bestow caudal neural character (i.e., any neural tissue that is not anterior forebrain). Therefore, neural tissue develops anterior character unless exposed to caudalizing signals. His induction-transformation model appears to match normal neural patterning more closely than the head-trunk organizer hypothesis.

\section{The influence of extrinsic signals in anterior neural induction}

It is broadly accepted that anterior neural induction requires the inhibition of the BMP, TGF $\beta$, and WNT/ $\beta$-catenin pathways. This model has been built from a bulk of evidence
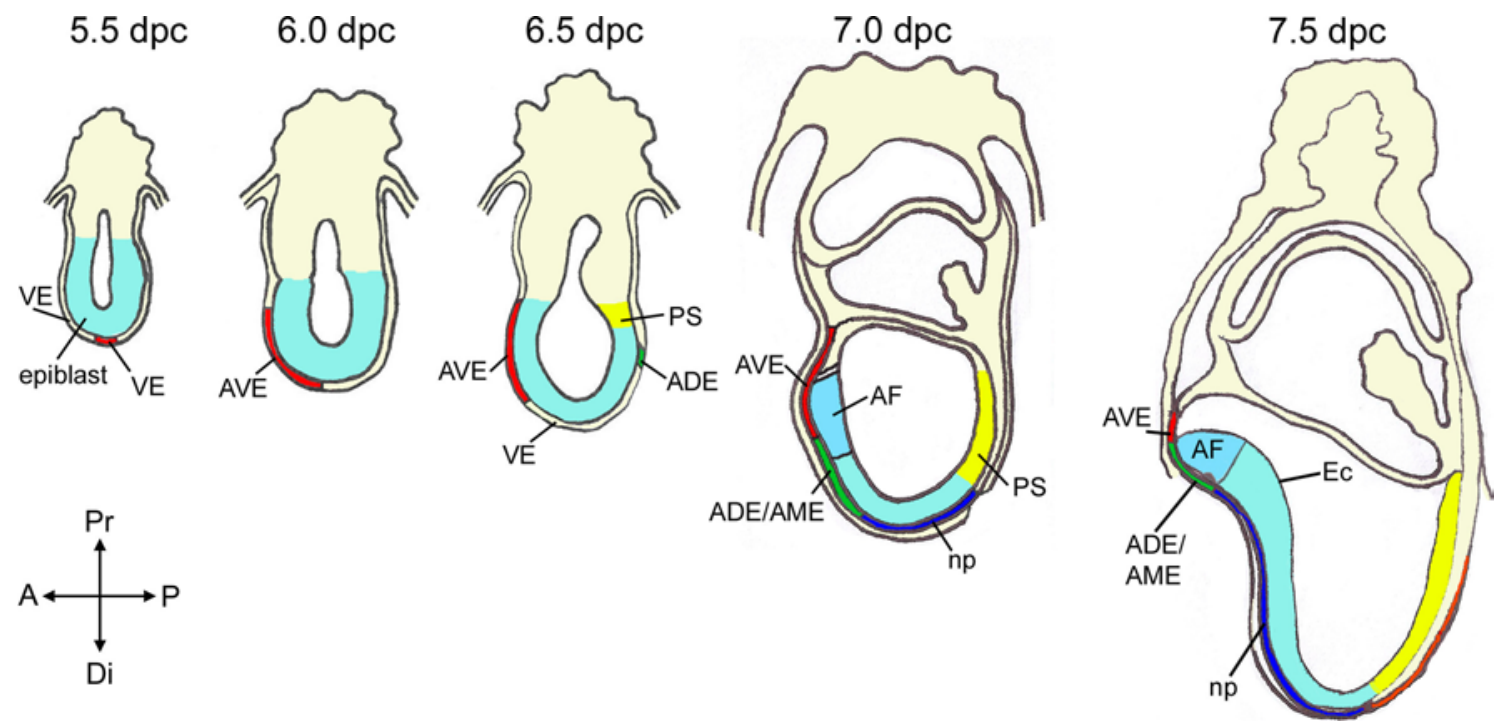

Fig. 2 Specification of tissues involved in patterning the anterior forebrain in the post-implantation mouse embryo and establishment of the anterio-posterior axis. AVE cells are induced to form by signals from the epiblast acting on $V E$ at the distal tip of the embryo by $5.5 \mathrm{dpc}$. AVE cells migrate anteriorly at $5.5 \mathrm{dpc}$, reach the boundary between the epiblast and extra-embryonic ectoderm in approximately $5-6 \mathrm{~h}$ and then start to move laterally. At $6.5 \mathrm{dpc}$, the $P S$ elongates and the anterior movements of the $A D E / A M E$ displace and intermingle with the AVE. The forebrain domain including future anterior

and posterior forebrain is patterned within the anterior portion of the presumptive neural ectoderm that overlies AVE and ADE/AME tissues. By $7.5 \mathrm{dpc}$, the prospective anterior forebrain neural ectoderm overlies the ADE/AME and posterior neural tissue is underlied by the notochordal plate. $V E$ visceral endoderm, $A V E$ anterior visceral endoderm, $A D E$ anterior definitive endoderm, $A M E$ anterior mesendoderm, $n p$ notochordal plate, $P S$ primitive streak, $A F$ anterior forebrain primordium, $E c$ neural ectoderm 
based on gene expression, loss- and gain-of-function experiments, chimeric analyses, and embryological datain Xenopus, zebrafish, chick, and mouse.

Historically, experiments in Xenopus had a major impact on the origin of this model. Animal caps that are cultured as intact explants become surface ectoderm, but if cells are disaggregated, hence released of extrinsic cues, they become neural ectoderm of anterior identity [55]. This has been one of the pillars sustaining the "default" model of neural induction, which suggests that at pre-gastrula stages, the default fate of naive ectoderm is usually neural (i.e., brain) rather than surface (i.e., skin) ectoderm [86]. In fact, treatment of dispersed animal cap cells with BMPs could convert them into epidermis [155]. These initial findings have been confirmed in different experimental models, including zebrafish $[15,44]$ and mice. Mouse embryos deficient for the BMP receptor 1A $\left(\right.$ Bmprla $\left.^{-/}\right)$, the main receptor for BMP2 and 4, exhibit premature neural induction at pre-gastrula stages with expression of anterior markers Hesxl and Six3 [35]. This is a similar phenotype to that observed in $\mathrm{Nodal}^{-/-}$mutants, and indeed $\mathrm{Bmprla}^{-/-}$embryos show no expression of Nodal $[21,35]$. These findings fit well with the concept that inhibition of BMP/TGF $\beta$ signaling is a prerequisite for neural induction. BMP inhibitors such as noggin and chordin are expressed in the vertebrate organizers and play a role in neural induction by preventing BMP signaling $[6,118$, 162]. This is beautifully exemplified in Xenopus, where the simultaneous depletion of noggin, chordin, and follistatin function by means of specific morpholinos, prevents the acquisition of neural fates demonstrating the critical role of BMP signaling inhibition during normal neural induction [66]. In addition, this research shows that there is a significant degree of functional redundancy, which may complicate the interpretation of data obtained in different animal models when addressing the requirement of specific signaling pathways [105].

Despite the robust evidence supporting the inhibition of BMP signaling for neural induction to occur, it was shown that this is not sufficient to induce an entire ectopic neural axis containing anterior and posterior components. The ability of Cerberus, a secreted inhibitor of nodal, BMP, and WNT molecules to induce an ectopic full axis when overexpressed in Xenopus confirmed the necessity to repress the BMP/TGF $\beta$ and WNT pathways for head formation to occur $[16,51,64,115]$. WNT molecules were found to exert caudalizing activity on neural tissue. For instance, treatment of chick ectodermal explants fated to become anterior forebrain could be transformed into posterior neural tissue by exposure to WNT molecules [108] and Wnt $8 \mathrm{c}$ over-expression in mouse embryos caused an expansion of midbrain markers at the expense of anterior forebrain [116]. These data suggest that once neural tissue has been induced, it must be protected from caudalizing activities that would bestow posterior identity, as proposed by Nieuwkoop.

Other molecules, such as retinoic acid (RA), were also shown to act as caudalizing factors, by promoting posterior fates in the neural plate [39]. In vivo, retinoic acid is synthesized from vitamin A (retinol) by the action of retinol dehydrogenases, which are expressed in the posterior regions of the embryo, but not in the anterior neural plate at the time of neural induction. In contrast, enzymes such as CYP26, a cytochrome P450 enzyme that degrades RA, is expressed at high levels in the anterior neural plate [56, 78]. This differential expression of synthesis and degradation enzymes is thought to create a RA signaling gradient along the AP axis (high-anterior and low-posterior) [90]. Fibroblast growth factors (FGFs) have also been shown to have caudalizing action on neural tissue in chick and Xenopus [97] and in mouse, exposure of prospective anterior forebrain tissue to FGF4 resulted in lack of expression of anterior forebrain markers and expansion of posterior markers [33].

FGF signaling has also been involved in the initiation of neural induction. Activation of FGF signaling has been proposed to be required prior to or independent to the inhibition of BMP signaling [43, 77, 88, 140]. Likewise, WNT signals have also been proposed to be required for neural induction in chick embryos [7, 112, 156]. However, there is also evidence suggesting that FGF signals are dispensable for the process of neural induction [154]. FGF signaling plays multiple and often contrasting roles in the early embryo as well as in pluripotent stem cells, and conclusions may vary depending on the particular experimental conditions and the assays used [81, 152]. Reconciling, at least partially, these discrepancies, elegant experiments have led to propose a model by which the activation of the FGF and WNT signaling pathways inhibits BMP signaling by promoting phosphorylation of Smad1 in a region of the molecule leading to its degradation and reduced nuclear localization [7, 40, 48, 113]. These findings are in line with experiments showing that inhibition of Smad1 and Smad2 is sufficient to induce neural character [23]. Together, these studies suggest that the activation of both the FGF and WNT pathways converge with the inhibition of BMP signaling at the levels of Smad1 and reinforces the idea that BMP signaling inhibition may be a conserved requirement for neural induction. They also suggest that there may be some species-specific differences regarding the temporal requirement of FGF signaling for neural induction. It will be important in the future to delineate the role of these specific pathways (e.g., retinoic acid, TGF $\beta$, BMP, FGF, and WNT) and we anticipate that in vitro neural differentiation experiments using mouse embryonic and epiblast stem cells may provide important insights $[26,41,54,84,102$, 104, 131, 137, 142]. 


\section{Signals from both the AVE and gastrula organizers are required for normal anterior neural induction}

The experiments described above led to a working model and identified major molecular players deployed during anterior neural induction. It is now clear that there is an involvement of at least two signaling centers for normal anterior neural induction, the AVE and the gastrula organizers. Relevant questions to further comprehend anterior neural induction are when during normal development, is the inhibition of the BMP/TGF $\beta$ and WNT pathways required? And which tissues do signals responsible for their inhibition derive from?

The visceral endoderm (VE) derives from a few cells lining the inner cell mass and the blastocoel cavity of the implanting $4.5 \mathrm{dpc}$ mouse embryo (Fig. 2). At $5.0 \mathrm{dpc}$, $\mathrm{VE}$ is a single cell epithelial sheet surrounding the naive epiblast, fated to give rise to the embryo proper and the extraembryonic ectoderm. At this stage, the precursors of the AVE are molecularly identifiable at the distal tip of the conceptus (distal visceral endoderm, DVE) by the expression of genes such as Hex, Leftyl (a secreted inhibitor of Nodal) and Cerl (an inhibitor of Nodal as well as WNT and BMP molecules) [11]. They are induced at the distal tip of the egg cylinder through the co-operative inductive action of the Nodal and MAPK signaling pathways, whose action is restricted to the distal tip by repressive signals from the extra-embryonic ectoderm [19, 24, 119]. Recent elegant lineage tracing experiments have demonstrated that the AVE is derived from specific primitive endoderm cells of the preimplantation blastocyst [144]. At the onset of gastrulation (6.5 dpc in the mouse), the AVE is located in the anteroproximal region of the embryo underneath the embryonic/ extraembryonic border. This final location of the AVE requires the antero-proximal movement of the DVE cells by cell intercalation into the VE cell layer [149, 150]. Therefore, it is clear that prior to the onset of gastrulation, the AVE has had ample opportunity to affect the patterning of the overlying anterior epiblast. However, it seems unlikely that the AVE can induce permanent neural character on its own; mouse embryos deficient for either Wnt 3 or Ctnnbl (encoding $\beta$-catenin), express AVE markers, but there is no activation of neural markers in the epiblast and therefore, no neural induction [62, 89, 94]. Corroborating these genetic data, ectopic transplantation of chick hypoblast can induce naïve ectoderm to express transient expression of neural markers, suggesting a priming effect during neural induction, but the stabilization of neural character requires BMP inhibitors and/or organizer activities [2].

Cell intermingling in the epiblast of the pregastrula mouse embryo is very high [49] and fate map analyses have shown that the most antero-proximal region of the epiblast overlying the AVE at these stages is not fated to give rise to the anterior neural plate. Rather, the prospective neural plate precursors are located in the antero-distal region of the embryo [85]. It is likely that the function of the AVE at these pre-gastrula stages is not only to "prime" the epiblast for anterior neural induction, but also to position the primitive streak, hence for the establishment of the AP axis. Genetic evidence from mouse mutants supports this idea. For example, embryos lacking Cerl and Leftyl show abnormal AVE patterning concomitant with the formation of multiple ectopic primitive streaks [114]. In addition, embryological studies have shown that removal of the chick hypoblast also leads to the appearance of multiple primitive streaks [14].

In the mouse, at $6.5 \mathrm{dpc}$ the PS forms in the posterior proximal region of the epiblast and will elongate during gastrulation so that by $7.5 \mathrm{dpc}$ it reaches the distal tip of the embryo, where the node will form. Neural induction is thought to take place in the early/mid-streak stage embryo, when $0 t x 2$ expression starts to be restricted to the anterior region of the epiblast. A few hours later, expression of anterior neural markers such as Hesxl and Six3 becomes evident. The inducing activities of the tip of the PS and the gastrula organizers have been extensively studied in several species, including the mouse, and the evidence strongly suggests that the AVE and the gastrula organizers act together to induce anterior neural character. For instance, the EGO cannot induce anterior forebrain marker expression when transplanted to the lateral side of a host mouse embryo, but does so when combined with the AVE [145]. In agreement with the need for signaling activity from the AVE, the Otx $2^{-/-}$, Foxa2 ${ }^{-/-}$, and $L h x 1^{-/-}$mutants have a molecularly identifiable EGO, but the AVE is not specified, resulting in an absence of anterior neural plate development $[1,5,73,117$, 126]. However, the EGO activity is also required; as previously discussed, mouse embryos deficient for either Wnt3 or Ctnnb1, express AVE markers at pre-gastrula stages, but do not form a PS and so do not express the molecular activities typical of the gastrula organizers, resulting in failure to undergo neural induction $[62,89]$. The EGO/node and its derivatives express many common genes, among them inhibitors of the TGF $\beta$ and WNT pathways such as Cerl, Dkkl, Nog (noggin), and Chrd (chordin), reinforcing the idea that they act synergistically during anterior neural induction. Of note, the activities required for anterior neural induction may still be present in the absence of discernible anatomical structures. This is exemplified in the Cripto ${ }^{-/-}$ mutants, which fail to gastrulate and so, neither the primitive streak or gastrula organizer are formed. However, genes normally expressed in the primitive streak and organizers are detected in the proximal region of the embryo. The AVE is also specified and typical AVE marker expression is observed at the distal tip of the mutant embryo. Despite this atypical arrangement of the AVE and organizer activities, anterior neural induction and patterning of the neural 
plate takes place in these mutants, although this is along the proximo-distal rather than AP axis [36].

Some experiments, however, have shown that the AVE and the mid-gastrula organizer (MGO, located at the distal tip of the primitive streak at mid-streak stage) can in isolation induce neural character. For instance, rabbit AVE is able to induce anterior neural character to naïve avian epiblast [74] and conversely, the MGO also appears to induce neural tissue in the absence of AVE [72]. There are several possible explanations for these findings, one being that the AVE or MGO may have the potential to induce anterior neural character when the experimental conditions are permissive. However, during normal development of the embryo both signaling centers are required. This is conceptually similar to the differences between regenerative and physiological potential of somatic stem cells when assessed in either transplantations or in lineage tracing experiments [132].

\section{Axial mesendoderm (AME) as a signaling center that maintains anterior neural character}

Once the anterior neural plate has been induced, evidenced by the expression of anterior neural markers such as Hesxl and Six 3 at early neural fold stages, it is important to ensure the maintenance of this character and prevent its posteriorization. As with AVE at earlier stages, anterior axial mesendoderm (AME) tissue underlying the neural plate, plays a critical role in performing this function. The AME is a mixed population comprised of (1) anterior definitive endoderm (ADE), which is fated to give rise to the anterior foregut and its derivatives (e.g., liver, stomach, pancreas) [147]; (2) prechordal plate, which refers to endodermal and mesenchymal cells underlying the anterior region of the neural plate, which will form the anterior hypothalamus, telencephalon, and eyes; (3) notochordal plate, which gives rise to the notochord, underlying the developing neural plate caudal to the anterior hypothalamus (Fig. 2). The term AME in mouse is usually used to refer to the ADE and mesodermal component of the prechordal plate underlying the anterior neural plate. The origin of the AME is the gastrula organizers and the node. From the tip of the PS and subsequently from the node, a population of ADE cells expressing Cerl and Hex move anteriorly within the VE to underlie the rostral neural epithelium [13, 147]. Notochordal plate cells derive from the node and will follow the ADE and prechordal plate, but its location is more restricted to the midline of the neural plate. Of note, within the mouse ADE, endoderm cells from the prechordal plate and notochordal plate initially move within the existing layer of VE and not underneath, therefore they need to intercalate with VE cells in their migration [141]. This causes part of the VE to become displaced into the extraembryonic region, mainly in the anterior portion of the embryo, but VE cells also become trapped and contribute to the endodermal lining of the adult gut [79]. The notochord will form a rod before somitogenesis and will be situated between the endoderm and neuroectoderm as in other vertebrates.

The inducing activities of the anterior AME are well established [20]. Explant experiments have shown the capacity of these cells to induce and/or maintain anterior character (i.e., Otx2 expression) in the vertebrate embryo [45]. In chick, the specific ablation of the ADE results in forebrain abnormalities with lack of telencephalic and eye development [158]. Likewise, absence of Hex, a transcription factor expressed in the ADE as it is formed from the tip of the PS, leads to patterning defects of the ADE and subsequent loss of anterior character (i.e., Hesxl and Six 3 expression) in the initially induced anterior neural plate [93]. The transcription factor $L h x 1$, and its co-factors $S s d p 1$ and $L d b 1$ are also necessary for normal brain development [42, 107, 126] and chimeric analyses have demonstrated its requirement in both the AVE and the AME [127]. The molecular activity of the anterior AME is thought to be similar to those of the AVE and gastrula organizers: to secrete inhibitors of the BMP/TGF $\beta$ and WNT pathways, hence protecting the anterior neural plate from posteriorizing signals. Supporting this notion, the AME expresses Dkkl, Cerl, Nog, and Chrd $[34,103,163]$ and lack of these inhibitors, either single or in combination, is associated with defects in anterior AME and anterior forebrain specification $[6,34,103,162]$.

The role of the AME in protecting the ANP from caudalizing signals is also important for the establishment of other signaling centers within the neural plate responsible for the expansion and further patterning of forebrain tissue. For further detail on the relevance of these local signaling centers within the ANP, we refer the reader to other reviews $[96,122,157]$. One such center was initially discovered from elegant experiments in zebrafish, whereby the removal of the most anterior neural plate cells (anterior neural border, ANB) caused severe forebrain truncations [61]. The relevance for the ANB was also demonstrated in mouse embryos by means of ablation experiments where FGF8 was found to act as an essential signal for normal development of the anterior forebrain [130], which was further confirmed in several genetic studies [100, 110, 111, 139]. In the $\mathrm{Hex}^{-/-}$mutants, which show severe forebrain defects including lack of the telencephalon and eyes, $F g f 8$ expression in the ANB is reduced or absent [93], and this appears to be caused by primary defects in ADE patterning. Corroborating this notion, removal of anterior definitive endoderm in chick leads to reduced $F g f 8$ expression in the ANB and forebrain, including eye defects [158]. Neural crest cells have been shown to play a critical role in the maintenance of $F g f 8$ expression in the ANR and expansion of the forebrain region [30, 31]. Another important signaling center in the 
forebrain is the zona limitants intrathalamica (zli), which is required for diencephalic development and is delineated by the expression of $\operatorname{Sh} h$ [67, 82, 125]. It develops within the neural tube, specifically between the prethalamus and thalamus (ventral and dorsal thalamus, respectively), but its position coincides with the boundary between the prechordal and notochordal plates [96, 122], suggesting that underlying tissues may also play a role in its formation.

In summary, the induction of the anterior neural plate and specification of the AP axis require the continued inhibition of signals that would bestow the naïve epiblast of the pregastrula embryo with a non-neural or caudal neural character. AVE, gastrula organizers and anterior AME are sources of secreted inhibitors that ensure the protection of a population of epiblast cells from these signals. In addition, the AME is required for the proper positioning of local signaling centers within the anterior neural plate that are responsible for further growth and development of the area.

\section{Intrinsic regulation of cell competence: an additional level of protection of anterior neural character}

In the previous section, we summarized a great deal of research pointing at the requirement for the anterior neural plate to be protected from signals that would transform it into posterior neural tissue. The activities of the AVE and gastrula organizers grant the epiblast anterior neural character, while the anterior AME acts to prevent its posterior transformation and refined patterning. This is achieved by the synergistic action of several secreted inhibitors. However, there are additional levels of protection within the neural plate itself, which prevent a posterior transformation of the ANP at stages when diffusion of secreted inhibitors from underlying tissues may be unable to reach this expanding region of the developing embryo.

Among the studied posteriorizing signals, it is the WNT/ $\beta$-catenin pathway that appears to be critical in preventing anterior neural character. In Xenopus embryos there is a high-caudal to low-rostral gradient of activated WNT pathway, consistent with observations in other vertebrates [68]. For instance, in transgenic mouse lines expressing lacZ under the control of TCF/LEF binding sites, it has been shown that the anterior neural plate is initially devoid of $\mathrm{X}$-gal staining, demonstrating that the WNT/ $\beta$-catenin pathway is not activated in anterior neural precursors [4, 92]. Likewise, expression of the WNT/ $\beta$-catenin target genes Axin 2 and Sp5 is detected in posterior regions but not in the anterior-most part of the neural plate [3]. The necessity of the suppression of this pathway has been further analyzed in vitro and in vivo. As previously discussed, WNT molecules can transform cells initially fated to be anterior to acquire a caudal neural character [108]. In mouse embryos, genetic studies have demonstrated the need to negatively modulate the levels of WNT signaling for normal head formation [46, 47, 87, 116]. In zebrafish, mutations resulting in over-activation of the WNT pathway lead to posterior transformation of telencephalon and eye tissues in favour of diencephalic fates [57]. The expression of several secreted inhibitors able to bind either WNT molecules or their receptors is high in the anterior neural plate and AME. For instance, the anterior neural border of the zebrafish embryo is the source of a secreted WNT inhibitor, $t l c$, which is required for normal telencephalic development $[60,61]$. However, the presence of these inhibitors is not the only way to ensure low levels of WNT signaling in the anterior neural plate.

Two early anterior neural markers, Hesxl and Six3, also contribute to inhibit the activation of the WNT pathway in a cell autonomous fashion (Fig. 3). Six $3^{-/-}$mutant embryos show anterior forebrain defects with impaired telencephalic, eye, and hypothalamic development at $10.5 \mathrm{dpc}$, even though the anterior neural plate is initially specified at pre-somitic stages and expresses markers such as Hesxl [80, 109]. Failure to maintain anterior forebrain marker expression is associated with a rostral expansion of posterior markers such as Pax3 and Wnt1. SIX3 can bind the Wntl promoter and inhibit Wntl expression in electroporated chick embryos, suggesting that SIX3 may repress the expression of Wntl in anterior forebrain, preventing its posterior transformation. The simultaneous removal of Six3 and Wnt1 in Six3 ${ }^{-/-} ; W_{n t 1}{ }^{-/-}$embryos improves diencephalic development, however, the telencephalon and eyes fail to develop as in the Six $3^{-/-}$mutants [83]. This suggests that SIX3 may be required for anterior neural plate development independently of its ability to repress Wntl expression $[8,22]$.

Very similar forebrain defects are observed in the Hes $x 1^{-/-}$mutants. Telencephalic vesicles and eyes are reduced or absent at early somite stages, but Six3 expression is unaffected at neural plate stages $[32,95]$. The lack of anterior forebrain is caused by a posterior transformation of the anterior neural plate, which was evidenced by the rostral expansion of posterior markers such as Wntl and Pax3. In addition, and confirming the change of fate of the ANP, genetic fate mapping studies on Hesxl ${ }^{\mathrm{Cre} /}{ }^{-}$; $R 26^{Y F P /+}$ (Hesxl null-mutants) and Hesxl ${ }^{\mathrm{Cre} /+} ; R_{26} 6^{\mathrm{YFP} /+}$ (normal) embryos have demonstrated that descendants of neural precursors initially fated to colonize the telencephalon and eyes end up populating posterior regions of the neural plate such as the thalamus, epithalamus, and pretectum [3]. In Hes $x 1^{-/-}$embryos, ectopic activation of the Wnt/ $\beta$ catenin signaling pathway, evidenced by Axin2 and Sp5 expression, is detectable at early somite stages prior to the onset of Wntl expression in the prospective midbrain/posterior forebrain region of the neural plate or $F g f 8$ expression in 
Fig. 3 Subdivision of the neural plate in discreet gene expression domains. a At presomitic/ early somite stages, in situ hybridization for Hesxl (red) and Pax2 (purple), marking the anterior forebrain and posterior forebrain/midbrain precursors, respectively. b The anterior forebrain primordium express Hesxl (red), and Pax3 (purple), delineates a posterior-lateral domain that gives rise to neural crest cells in an older embryo. Note that these domains do not overlap (adapted with permission from Disease Models and Mechanisms (Sajedi et al. (2008), Disease Models and Mechanisms 1 (4-5), 241-254)
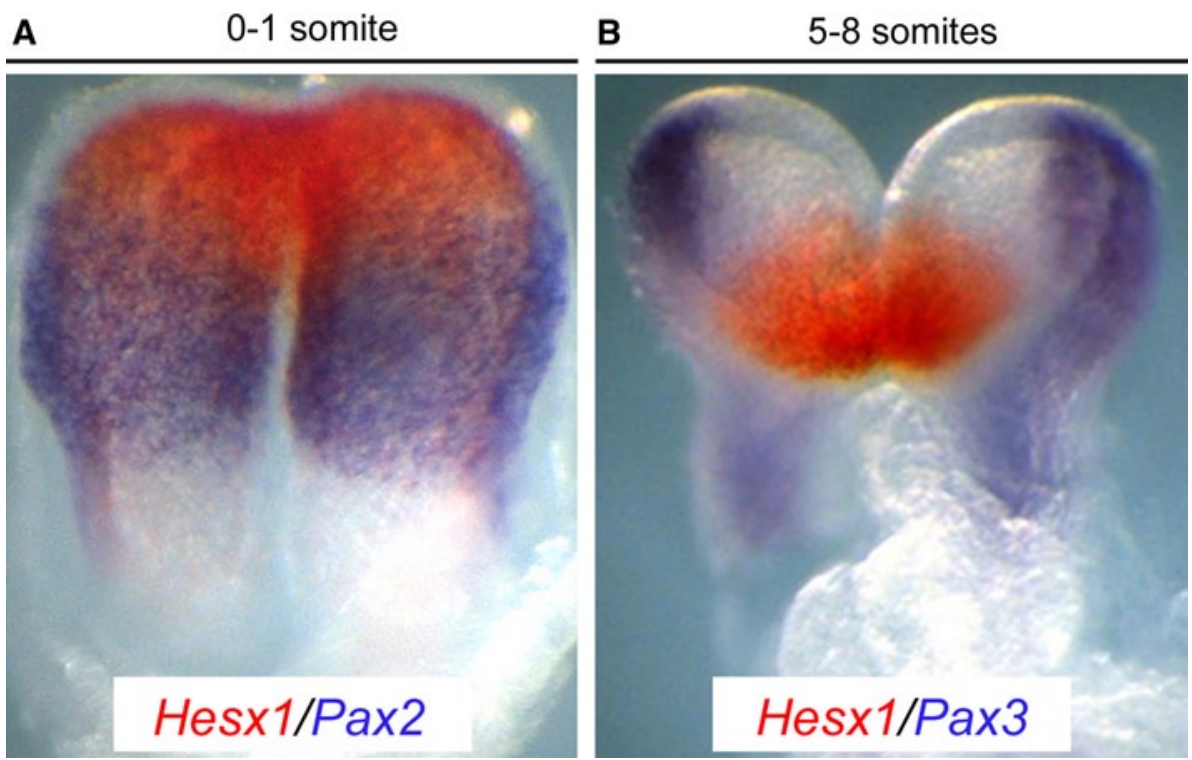

the ANR. This suggests that the observed reduction of the Fgf8 expression domain in the ANR and the expansion of the $W n t 1$ expression domain are a consequence of the ectopic activation of the WNT/ $\beta$-catenin pathway in the ANP. At the molecular level, gene profiling of isolated anterior forebrain precursors has demonstrated the ectopic activation of the WNT pathway in Hesxl-deficient embryos relative to controls [4]. Therefore, HESX1, as well as SIX3, may regulate the competence of the ANP making it unresponsive to the WNT molecules that are secreted at posterior levels (WNT1 and WNT3a). The regulation of cell competence, i.e., the ability of a cell to either respond or not to a given signal, is an important factor in cell fate specification that usually attracts less attention than the function of the inductive signals themselves [91, 133, 148]. For example, the expression domains of Six3 and Irx3 (a member of the Iroquois family of homeoproteins with a role in neural induction and patterning) have been proposed to confer distinct competence to inducing signals to specify anterior versus posterior neural plate identity [52, 53, 75, 120]. Analysis of the Tcf7l1 (Tcf3) mutants supports the hypothesis that SIX3 and HESX1 may regulate cell competence within the anterior neural plate.

In mouse, $T c f 3$-deficient embryos undergo gastrulation, but exhibit variable degrees of defects, including primitive streak and axis duplications, supernumerary neural folds, and neural patterning defects involving expansion of midbrain at the expense of forebrain and hindbrain tissues [99]. At the molecular level, TCF3 acts as a repressor of WNT/ $\beta$-catenin targets in Xenopus and zebrafish $[18,37,69]$. Genetic evidence in mouse has demonstrated that the expression of a mutant TCF3 protein lacking the $\beta$-catenin-interacting domain rescues the gastrulation and neural plate defects observed in the $T c f 3^{-/-}$[160]. In addition, the conditional ablation of $T c f 3$ within the anterior forebrain in Hesx $1^{\text {Cre/+}} ; T c f 3^{\text {loxP/loxP }}$ embryos leads to defects that are very similar if not identical to those observed in Hes $x 1^{-/-}$and Six $3^{-/-}$mutants, such as small or absent telencephalon, hypothalamus, and eyes [4]. These data suggest that TCF3 is required for normal forebrain development as a transcriptional repressor of WNT/ $\beta$-catenin targets. In addition, as Tcf3, Hesx 1 , and Six3 are mostly co-expressed in the anterior neural plate at presomitic stages, it seems plausible that the three may co-operate at the protein level, ensuring that anterior forebrain precursors do not activate the expression of WNT targets, which could confer a posterior identity. Supporting this notion, there is a genetic interaction between Hesxl and Six3 as well as between Hesxl and $T c f 3$, indicating that a minimum gene dose is required to maintain anterior neural plate identity [4, 50]. Although speculative, it is possible that $R x$, another transcription factor may co-operate with Hesx 1, Six3, and Tcf3 in the maintenance of anterior identity [98]. Together, these data suggest that there is an additional level of control of the WNT pathway involving the expression of transcriptional repressors within the ANP that act to prevent an ectopic response to WNT signaling (Fig. 4). Further research will reveal the exact mechanisms by which these actions are mediated.

In conclusion, research over the last years has revealed the principles that regulate the development of the anterior forebrain at early stages of embryogenesis. There is a perfect interplay of signaling centers during normal morphogenesis of the embryo to ensure that the anterior forebrain is protected from caudalizing factors. This is initiated by the AVE, embellished by the ADE/AME, and reinforced by transcriptional repressors regulating cell competence within the anterior forebrain itself. 


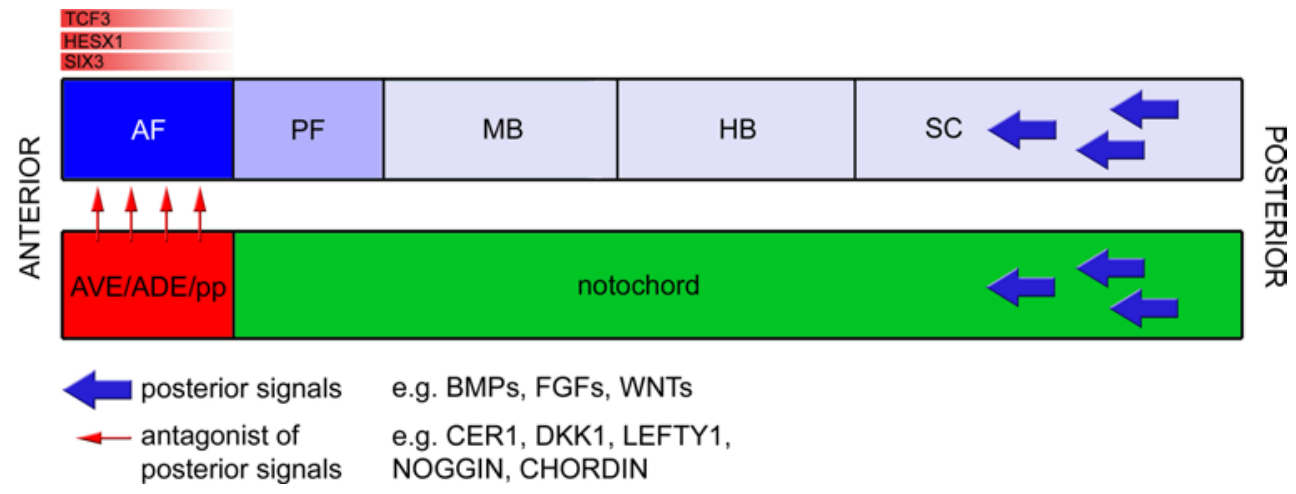

Fig. 4 A host of signals act in concert to confer anterior forebrain identity. Signals such as WNTs, FGFs, and BMPs exert a posteriorizing action on the neural plate (blue arrows). Counteracting activation of the respective pathways in the anterior forebrain, secreted inhibitors such as Cerberus, Lefty1, Dkkl, Noggin, and Chordin (red arrows) are released by the underlying $A V E, A D E$, and prechordal plate. Within the prospective anterior forebrain, intrinsic factors such

Acknowledgments The authors wish to apologize for any omission as we may have inadvertently left some relevant work un-cited. We are grateful to Shankar Srinivas, Tristan Rodriguez, and Paul Le Tissier, for comments and suggestions. The authors are funded by the Wellcome Trust grant 084361 .

Open Access This article is distributed under the terms of the Creative Commons Attribution License which permits any use, distribution, and reproduction in any medium, provided the original author(s) and the source are credited.

\section{References}

1. Acampora D, Avantaggiato V, Tuorto F, Briata P, Corte G, Simeone A (1998) Visceral endoderm-restricted translation of Otx1 mediates recovery of Otx 2 requirements for specification of anterior neural plate and normal gastrulation. Development 125(24):5091-5104

2. Albazerchi A, Stern CD (2007) A role for the hypoblast (AVE) in the initiation of neural induction, independent of its ability to position the primitive streak. Dev Biol 301(2):489-503. doi:10.1016/j.ydbio.2006.08.057

3. Andoniadou CL, Signore M, Sajedi E, Gaston-Massuet C, Kelberman D, Burns AJ, Itasaki N, Dattani M, Martinez-Barbera JP (2007) Lack of the murine homeobox gene Hesxl leads to a posterior transformation of the anterior forebrain. Development 134(8):1499-1508. doi:10.1242/dev.02829

4. Andoniadou CL, Signore M, Young RM, Gaston-Massuet C, Wilson SW, Fuchs E, Martinez-Barbera JP (2011) HESX1and TCF3-mediated repression of Wnt/beta-catenin targets is required for normal development of the anterior forebrain. Development 138(22):4931-4942. doi:10.1242/dev.066597

5. Ang SL, Rossant J (1994) HNF-3 beta is essential for node and notochord formation in mouse development. Cell 78(4):561-574

6. Bachiller D, Klingensmith J, Kemp C, Belo JA, Anderson RM, May SR, McMahon JA, McMahon AP, Harland RM, Rossant J, De Robertis EM (2000) The organizer factors chordin and noggin are required for mouse forebrain development. Nature 403(6770):658-661. doi:10.1038/35001072 as HESX1, SIX3, and TCF3, aid in regulating the competence of neural tissue to not respond to posteriorizing signals, possibly by preventing the expression of target genes of these pathways, hence maintaining anterior forebrain identity. $A F$ anterior forebrain, $P F$ posterior forebrain, $M B$ midbrain, $H B$ hindbrain, $S C$ spinal cord, $A V E$ anterior visceral endoderm, $A D E$ anterior definitive endoderm, $p p$ prechordal plate

7. Baker JC, Beddington RS, Harland RM (1999) Wnt signaling in Xenopus embryos inhibits bmp4 expression and activates neural development. Genes Dev 13(23):3149-3159

8. Beccari L, Conte I, Cisneros E, Bovolenta P (2012) Sox2-mediated differential activation of Six3.2 contributes to forebrain patterning. Development 139(1):151-164. doi:10.1242/dev.067660

9. Beccari L, Marco-Ferreres R, Bovolenta P (2012) The logic of gene regulatory networks in early vertebrate forebrain patterning. Mech Dev. doi:10.1016/j.mod.2012.10.004

10. Beddington RS (1994) Induction of a second neural axis by the mouse node. Development 120(3):613-620

11. Beddington RS, Robertson EJ (1998) Anterior patterning in mouse. Trends Genet 14(7):277-284

12. Beddington RS, Robertson EJ (1999) Axis development and early asymmetry in mammals. Cell 96(2):195-209

13. Belo JA, Bouwmeester T, Leyns L, Kertesz N, Gallo M, Follettie M, De Robertis EM (1997) Cerberus-like is a secreted factor with neutralizing activity expressed in the anterior primitive endoderm of the mouse gastrula. Mech Dev 68(1-2):45-57

14. Bertocchini F, Stern CD (2002) The hypoblast of the chick embryo positions the primitive streak by antagonizing nodal signaling. Dev Cell 3(5):735-744

15. Bielen H, Houart C (2012) BMP signaling protects telencephalic fate by repressing eye identity and its Cxcr4-dependent morphogenesis. Dev Cell 23(4):812-822. doi:10.1016/ j.devcel.2012.09.006

16. Bouwmeester T, Kim S, Sasai Y, Lu B, De Robertis EM (1996) Cerberus is a head-inducing secreted factor expressed in the anterior endoderm of Spemann's organizer. Nature 382(6592):595601. doi:10.1038/382595a0

17. Boyl PP, Signore M, Acampora D, Martinez-Barbera JP, Ilengo C, Annino A, Corte G, Simeone A (2001) Forebrain and midbrain development requires epiblast-restricted Otx2 translational control mediated by its 3' UTR. Development 128(15):2989-3000

18. Brannon M, Brown JD, Bates R, Kimelman D, Moon RT (1999) $\mathrm{XCtBP}$ is a XTcf-3 co-repressor with roles throughout Xenopus development. Development 126(14):3159-3170

19. Brennan J, Lu CC, Norris DP, Rodriguez TA, Beddington RS, Robertson EJ (2001) Nodal signalling in the epiblast patterns the early mouse embryo. Nature 411(6840):965-969. doi: $10.1038 / 35082103$ 
20. Camus A, Davidson BP, Billiards S, Khoo P, Rivera-Perez JA, Wakamiya M, Behringer RR, Tam PP (2000) The morphogenetic role of midline mesendoderm and ectoderm in the development of the forebrain and the midbrain of the mouse embryo. Development 127(9):1799-1813

21. Camus A, Perea-Gomez A, Moreau A, Collignon J (2006) Absence of nodal signaling promotes precocious neural differentiation in the mouse embryo. Dev Biol 295(2):743-755. doi:10.1016/j.ydbio.2006.03.047

22. Carlin D, Sepich D, Grover VK, Cooper MK, Solnica-Krezel L, Inbal A (2012) Six3 cooperates with Hedgehog signaling to specify ventral telencephalon by promoting early expression of Foxg1a and repressing Wnt signaling. Development 139(14):2614-2624. doi:10.1242/dev.076018

23. Chang C, Harland RM (2007) Neural induction requires continued suppression of both Smad1 and Smad2 signals during gastrulation. Development 134(21):3861-3872. doi:10.1242/ dev.007179

24. Clements M, Pernaute B, Vella F, Rodriguez TA (2011) Crosstalk between nodal/activin and MAPK p38 signaling is essential for anterior-posterior axis specification. Curr Biol 21(15):12891295. doi:10.1016/j.cub.2011.06.048

25. Cobos I, Shimamura K, Rubenstein JL, Martinez S, Puelles L (2001) Fate map of the avian anterior forebrain at the foursomite stage, based on the analysis of quail-chick chimeras. Dev Biol 239(1):46-67. doi:10.1006/dbio.2001.0423

26. Cohen MA, Itsykson P, Reubinoff BE (2010) The role of FGFsignaling in early neural specification of human embryonic stem cells. Dev Biol 340(2):450-458. doi:10.1016/j.ydbio. 2010.01.030

27. Couly G, Le Douarin NM (1988) The fate map of the cephalic neural primordium at the presomitic to the 3-somite stage in the avian embryo. Development 103(Suppl):101-113

28. Couly GF, Le Douarin NM (1985) Mapping of the early neural primordium in quail-chick chimeras. I. Developmental relationships between placodes, facial ectoderm, and prosencephalon. Dev Biol 110(2):422-439

29. Couly GF, Le Douarin NM (1987) Mapping of the early neural primordium in quail-chick chimeras. II. The prosencephalic neural plate and neural folds: implications for the genesis of cephalic human congenital abnormalities. Dev Biol 120(1):198-214

30. Creuzet SE (2009) Regulation of pre-otic brain development by the cephalic neural crest. Proc Natl Acad Sci USA 106(37):15774-15779. doi:10.1073/pnas.0906072106

31. Creuzet SE, Martinez S, Le Douarin NM (2006) The cephalic neural crest exerts a critical effect on forebrain and midbrain development. Proc Natl Acad Sci USA 103(38):14033-14038. doi:10.1073/pnas.0605899103

32. Dattani MT, Martinez-Barbera JP, Thomas PQ, Brickman JM, Gupta R, Martensson IL, Toresson H, Fox M, Wales JK, Hindmarsh PC, Krauss S, Beddington RS, Robinson IC (1998) Mutations in the homeobox gene HESX1/Hesx1 associated with septo-optic dysplasia in human and mouse. Nat Genet 19(2):125-133. doi:10.1038/477

33. Davidson BP, Cheng L, Kinder SJ, Tam PP (2000) Exogenous FGF-4 can suppress anterior development in the mouse embryo during neurulation and early organogenesis. Dev Biol 221(1):41-52. doi:10.1006/dbio.2000.9663

34. del Barco Barrantes I, Davidson G, Grone HJ, Westphal H, Niehrs C (2003) Dkk1 and noggin cooperate in mammalian head induction. Genes Dev 17(18):2239-2244. doi:10.1101/ gad.269103

35. Di-Gregorio A, Sancho M, Stuckey DW, Crompton LA, Godwin J, Mishina Y, Rodriguez TA (2007) BMP signalling inhibits premature neural differentiation in the mouse embryo. Development 134(18):3359-3369. doi:10.1242/dev.005967
36. Ding J, Yang L, Yan YT, Chen A, Desai N, Wynshaw-Boris A, Shen MM (1998) Cripto is required for correct orientation of the anterior-posterior axis in the mouse embryo. Nature 395(6703):702-707. doi:10.1038/27215

37. Dorsky RI, Itoh M, Moon RT, Chitnis A (2003) Two tcf3 genes cooperate to pattern the zebrafish brain. Development 130(9):1937-1947

38. Dufort D, Schwartz L, Harpal K, Rossant J (1998) The transcription factor HNF3beta is required in visceral endoderm for normal primitive streak morphogenesis. Development 125(16):3015-3025

39. Durston AJ, Timmermans JP, Hage WJ, Hendriks HF, de Vries NJ, Heideveld M, Nieuwkoop PD (1989) Retinoic acid causes an anteroposterior transformation in the developing central nervous system. Nature 340(6229):140-144. doi:10.1038/340140a0

40. Eivers E, Fuentealba LC, De Robertis EM (2008) Integrating positional information at the level of Smad1/5/8. Curr Opin Genet Dev 18(4):304-310. doi:10.1016/j.gde.2008.06.001

41. Engberg N, Kahn M, Petersen DR, Hansson M, Serup P (2010) Retinoic acid synthesis promotes development of neural progenitors from mouse embryonic stem cells by suppressing endogenous. Wnt-dependent nodal signaling. Stem Cells 28(9): 1498-1509. doi:10.1002/stem.479

42. Enkhmandakh B, Makeyev AV, Bayarsaihan D (2006) The role of the proline-rich domain of Ssdp1 in the modular architecture of the vertebrate head organizer. Proc Natl Acad Sci USA 103(31):11631-11636. doi:10.1073/pnas.0605209103

43. Ericson J, Norlin S, Jessell TM, Edlund T (1998) Integrated FGF and BMP signaling controls the progression of progenitor cell differentiation and the emergence of pattern in the embryonic anterior pituitary. Development 125(6):1005-1015

44. Fekany-Lee K, Gonzalez E, Miller-Bertoglio V, Solnica-Krezel L (2000) The homeobox gene bozozok promotes anterior neuroectoderm formation in zebrafish through negative regulation of BMP2/4 and Wnt pathways. Development 127(11):2333-2345

45. Foley AC, Storey KG, Stern CD (1997) The prechordal region lacks neural inducing ability, but can confer anterior character to more posterior neuroepithelium. Development 124(15):2983-2996

46. Fossat N, Jones V, Garcia-Garcia MJ, Tam PP (2012) Modulation of WNT signaling activity is key to the formation of the embryonic head. Cell Cycle 11(1):26-32. doi:10.4161/ cc.11.1.18700

47. Fossat N, Jones V, Khoo PL, Bogani D, Hardy A, Steiner K, Mukhopadhyay M, Westphal H, Nolan PM, Arkell R, Tam PP (2011) Stringent requirement of a proper level of canonical WNT signalling activity for head formation in mouse embryo. Development 138(4):667-676. doi:10.1242/dev.052803

48. Fuentealba LC, Eivers E, Ikeda A, Hurtado C, Kuroda H, Pera EM, De Robertis EM (2007) Integrating patterning signals: Wnt/GSK3 regulates the duration of the BMP/Smad1 signal. Cell 131(5):980-993. doi:10.1016/j.cell.2007.09.027

49. Gardner RL, Cockroft DL (1998) Complete dissipation of coherent clonal growth occurs before gastrulation in mouse epiblast. Development 125(13):2397-2402

50. Gaston-Massuet C, Andoniadou CL, Signore M, Sajedi E, Bird S, Turner JM, Martinez-Barbera JP (2008) Genetic interaction between the homeobox transcription factors HESX1 and SIX3 is required for normal pituitary development. Dev Biol 324(2):322-333. doi:10.1016/j.ydbio.2008.08.008

51. Glinka A, Wu W, Onichtchouk D, Blumenstock C, Niehrs C (1997) Head induction by simultaneous repression of Bmp and Wnt signalling in Xenopus. Nature 389(6650):517-519. doi: $10.1038 / 39092$

52. Gomez-Skarmeta J, de La Calle-Mustienes E, Modolell J (2001) The Wnt-activated Xiro1 gene encodes a repressor that 
is essential for neural development and downregulates Bmp4. Development 128(4):551-560

53. Gomez-Skarmeta JL, Modolell J (2002) Iroquois genes: genomic organization and function in vertebrate neural development. Curr Opin Genet Dev 12(4):403-408

54. Greber B, Coulon P, Zhang M, Moritz S, Frank S, MullerMolina AJ, Arauzo-Bravo MJ, Han DW, Pape HC, Scholer HR (2011) FGF signalling inhibits neural induction in human embryonic stem cells. EMBO J 30(24):4874-4884. doi:10.1038 /emboj.2011.407

55. Grunz H, Tacke L (1989) Neural differentiation of Xenopus laevis ectoderm takes place after disaggregation and delayed reaggregation without inducer. Cell Differ Dev 28(3):211-217

56. Halilagic A, Zile MH, Studer M (2003) A novel role for retinoids in patterning the avian forebrain during presomite stages. Development 130(10):2039-2050

57. Heisenberg CP, Houart C, Take-Uchi M, Rauch GJ, Young N, Coutinho P, Masai I, Caneparo L, Concha ML, Geisler R, Dale TC, Wilson SW, Stemple DL (2001) A mutation in the Gsk3binding domain of zebrafish Masterblind/Axin1 leads to a fate transformation of telencephalon and eyes to diencephalon. Genes Dev 15(11):1427-1434. doi:10.1101/gad.194301

58. Ho CY, Houart C, Wilson SW, Stainier DY (1999) A role for the extraembryonic yolk syncytial layer in patterning the zebrafish embryo suggested by properties of the hex gene. Curr Biol 9(19):1131-1134

59. Hoch RV, Rubenstein JL, Pleasure S (2009) Genes and signaling events that establish regional patterning of the mammalian forebrain. Semin Cell Dev Biol 20(4):378-386. doi:10.1016/j.semcdb.2009.02.005

60. Houart C, Caneparo L, Heisenberg C, Barth K, Take-Uchi M, Wilson S (2002) Establishment of the telencephalon during gastrulation by local antagonism of Wnt signaling. Neuron 35(2):255-265

61. Houart C, Westerfield M, Wilson SW (1998) A small population of anterior cells patterns the forebrain during zebrafish gastrulation. Nature 391(6669):788-792. doi:10.1038/35853

62. Huelsken J, Vogel R, Brinkmann V, Erdmann B, Birchmeier C, Birchmeier W (2000) Requirement for beta-catenin in anteriorposterior axis formation in mice. J Cell Biol 148(3):567-578

63. Inoue $\mathrm{T}$, Nakamura $\mathrm{S}$, Osumi $\mathrm{N}$ (2000) Fate mapping of the mouse prosencephalic neural plate. Dev Biol 219(2):373-383. doi:10.1006/dbio.2000.9616

64. Inui M, Montagner M, Ben-Zvi D, Martello G, Soligo S, Manfrin A, Aragona M, Enzo E, Zacchigna L, Zanconato F, Azzolin L, Dupont S, Cordenonsi M, Piccolo S (2012) Self-regulation of the head-inducing properties of the Spemann organizer. Proc Natl Acad Sci USA. doi:10.1073/pnas.1203000109

65. Jones CM, Broadbent J, Thomas PQ, Smith JC, Beddington RS (1999) An anterior signalling centre in Xenopus revealed by the homeobox gene XHex. Curr Biol 9(17):946-954

66. Khokha MK, Yeh J, Grammer TC, Harland RM (2005) Depletion of three BMP antagonists from Spemann's organizer leads to a catastrophic loss of dorsal structures. Dev Cell 8(3):401411. doi:10.1016/j.devcel.2005.01.013

67. Kiecker C, Lumsden A (2004) Hedgehog signaling from the ZLI regulates diencephalic regional identity. Nat Neurosci 7(11):1242-1249. doi:10.1038/nn1338

68. Kiecker C, Niehrs C (2001) A morphogen gradient of Wnt/betacatenin signalling regulates anteroposterior neural patterning in Xenopus. Development 128(21):4189-4201

69. Kim $\mathrm{CH}$, Oda $\mathrm{T}$, Itoh $\mathrm{M}$, Jiang $\mathrm{D}$, Artinger $\mathrm{KB}$, Chandrasekharappa SC, Driever W, Chitnis AB (2000) Repressor activity of Headless/Tcf3 is essential for vertebrate head formation. Nature 407(6806):913-916. doi:10.1038/35038097
70. Kimura-Yoshida C, Nakano H, Okamura D, Nakao K, Yonemura S, Belo JA, Aizawa S, Matsui Y, Matsuo I (2005) Canonical Wnt signaling and its antagonist regulate anterior-posterior axis polarization by guiding cell migration in mouse visceral endoderm. Dev Cell 9(5):639-650. doi:10.1016/j.devcel.2005.09.011

71. Kimura-Yoshida C, Tian E, Nakano H, Amazaki S, Shimokawa K, Rossant J, Aizawa S, Matsuo I (2007) Crucial roles of Foxa2 in mouse anterior-posterior axis polarization via regulation of anterior visceral endoderm-specific genes. Proc Natl Acad Sci USA 104(14):5919-5924. doi:10.1073/pnas.0607779104

72. Kinder SJ, Tsang TE, Wakamiya M, Sasaki H, Behringer RR, Nagy A, Tam PP (2001) The organizer of the mouse gastrula is composed of a dynamic population of progenitor cells for the axial mesoderm. Development 128(18):3623-3634

73. Klingensmith J, Ang SL, Bachiller D, Rossant J (1999) Neural induction and patterning in the mouse in the absence of the node and its derivatives. Dev Biol 216(2):535-549. doi:10.1006/d bio. 1999.9525

74. Knoetgen H, Teichmann U, Wittler L, Viebahn C, Kessel M (2000) Anterior neural induction by nodes from rabbits and mice. Dev Biol 225(2):370-380. doi:10.1006/dbio.2000.9834

75. Kobayashi D, Kobayashi M, Matsumoto K, Ogura T, Nakafuku M, Shimamura K (2002) Early subdivisions in the neural plate define distinct competence for inductive signals. Development 129(1):83-93

76. Kondoh H, Kamachi Y (2010) SOX-partner code for cell specification: regulatory target selection and underlying molecular mechanisms. Int J Biochem Cell Biol 42(3):391-399. doi:10.1016/j.biocel.2009.09.003

77. Kudoh T, Concha ML, Houart C, Dawid IB, Wilson SW (2004) Combinatorial Fgf and Bmp signalling patterns the gastrula ectoderm into prospective neural and epidermal domains. Development 131(15):3581-3592. doi:10.1242/dev.01227

78. Kudoh T, Wilson SW, Dawid IB (2002) Distinct roles for Fgf, Wnt and retinoic acid in posteriorizing the neural ectoderm. Development 129(18):4335-4346

79. Kwon GS, Viotti M, Hadjantonakis AK (2008) The endoderm of the mouse embryo arises by dynamic widespread intercalation of embryonic and extraembryonic lineages. Dev Cell 15(4):509_ 520. doi:10.1016/j.devcel.2008.07.017

80. Lagutin OV, Zhu CC, Kobayashi D, Topczewski J, Shimamura K, Puelles L, Russell HR, McKinnon PJ, Solnica-Krezel L, Oliver G (2003) Six3 repression of Wnt signaling in the anterior neuroectoderm is essential for vertebrate forebrain development. Genes Dev 17(3):368-379. doi:10.1101/gad.1059403

81. Lanner F, Rossant J (2010) The role of FGF/Erk signaling in pluripotent cells. Development 137(20):3351-3360. doi:10.124 2/dev.050146

82. Larsen CW, Zeltser LM, Lumsden A (2001) Boundary formation and compartition in the avian diencephalon. J Neurosci 21(13):4699-4711

83. Lavado A, Lagutin OV, Oliver G (2008) Six 3 inactivation causes progressive caudalization and aberrant patterning of the mammalian diencephalon. Development 135(3):441-450. doi:10.124 2/dev.010082

84. LaVaute TM, Yoo YD, Pankratz MT, Weick JP, Gerstner JR, Zhang SC (2009) Regulation of neural specification from human embryonic stem cells by BMP and FGF. Stem Cells 27(8):17411749. doi:10.1002/stem.99

85. Lawson KA, Meneses JJ, Pedersen RA (1991) Clonal analysis of epiblast fate during germ layer formation in the mouse embryo. Development 113(3):891-911

86. Levine AJ, Brivanlou AH (2007) Proposal of a model of mammalian neural induction. Dev Biol 308(2):247-256. doi:10.1016/j.ydbio.2007.05.036 
87. Lewis SL, KhooPL, DeYoungRA, SteinerK, WilcockC,Mukhopadhyay M, Westphal H, Jamieson RV, Robb L, Tam PP (2008) Dkk1 and Wnt3 interact to control head morphogenesis in the mouse. Development 135(10):1791-1801. doi:10.1242/dev.018853

88. Linker C, Stern CD (2004) Neural induction requires BMP inhibition only as a late step, and involves signals other than FGF and Wnt antagonists. Development 131(22):5671-5681. doi:10.1242/dev.01445

89. Liu P, Wakamiya M, Shea MJ, Albrecht U, Behringer RR, Bradley A (1999) Requirement for Wnt3 in vertebrate axis formation. Nat Genet 22(4):361-365. doi:10.1038/11932

90. Maden M (1999) Heads or tails? Retinoic acid will decide. Bioessays 21(10):809-812. doi:10.1002/(sici)1521-1878(199910)21: 10<809:aid-bies2>3.0.co;2-0

91. Manuel M, Martynoga B, Yu T, West JD, Mason JO, Price DJ (2010) The transcription factor Foxg1 regulates the competence of telencephalic cells to adopt subpallial fates in mice. Development 137(3):487-497. doi:10.1242/dev.039800

92. Maretto S, Cordenonsi M, Dupont S, Braghetta P, Broccoli V, Hassan AB, Volpin D, Bressan GM, Piccolo S (2003) Mapping Wnt/beta-catenin signaling during mouse development and in colorectal tumors. Proc Natl Acad Sci USA 100(6):3299-3304

93. Martinez Barbera JP, Clements M, Thomas P, Rodriguez T, Meloy D, Kioussis D, Beddington RS (2000) The homeobox gene Hex is required in definitive endodermal tissues for normal forebrain, liver and thyroid formation. Development 127(11):2433-2445

94. Martinez-Barbera JP, Beddington RS (2001) Getting your head around Hex and Hesx 1: forebrain formation in mouse. Int J Dev Biol 45(1):327-336

95. Martinez-Barbera JP, Rodriguez TA, Beddington RS (2000) The homeobox gene Hesx1 is required in the anterior neural ectoderm for normal forebrain formation. Dev Biol 223(2):422-430. doi:10.1006/dbio.2000.9757

96. Martinez-Ferre A, Martinez S (2012) Molecular regionalization of the diencephalon. Front Neurosci 6:73. doi:10.3389/fn ins.2012.00073

97. Mason I (2007) Initiation to end point: the multiple roles of fibroblast growth factors in neural development. Nat Rev Neurosci 8(8):583-596. doi:10.1038/nrn2189

98. Mathers PH, Grinberg A, Mahon KA, Jamrich M (1997) The $\mathrm{Rx}$ homeobox gene is essential for vertebrate eye development. Nature 387(6633):603-607. doi:10.1038/42475

99. Merrill BJ, Pasolli HA, Polak L, Rendl M, Garcia-Garcia MJ, Anderson KV, Fuchs E (2004) Tcf3: a transcriptional regulator of axis induction in the early embryo. Development 131(2):263274. doi: $10.1242 / \mathrm{dev} .00935$

100. Meyers EN, Lewandoski M, Martin GR (1998) An Fgf8 mutant allelic series generated by Cre- and Flp-mediated recombination. Nat Genet 18(2):136-141. doi:10.1038/ng0298-136

101. Miura S, Singh AP, Mishina Y (2010) Bmprla is required for proper migration of the AVE through regulation of Dkk1 expression in the pre-streak mouse embryo. Dev Biol 341(1):246-254. doi:10.1016/j.ydbio.2010.02.038

102. Morizane A, Doi D, Kikuchi T, Nishimura K, Takahashi J (2011) Small-molecule inhibitors of bone morphogenic protein and activin/nodal signals promote highly efficient neural induction from human pluripotent stem cells. J Neurosci Res 89(2):117126. doi:10.1002/jnr.22547

103. Mukhopadhyay M, Shtrom S, Rodriguez-Esteban C, Chen L, Tsukui T, Gomer L, Dorward DW, Glinka A, Grinberg A, Huang SP, Niehrs C, Izpisua Belmonte JC, Westphal H (2001) Dickkopf1 is required for embryonic head induction and limb morphogenesis in the mouse. Dev Cell 1(3):423-434

104. Nichols J, Smith A (2011) The origin and identity of embryonic stem cells. Development 138(1):3-8. doi:10.1242/dev.050831
105. Niehrs C (2005) Axis formation: redundancy rules. Curr Biol 15(10):391-393. doi:10.1016/j.cub.2005.05.002

106. Nieuwkoop PD, Boterenbrood EC, Kremer A, Bloemsma FFSN, Hoessels ELMJ, Meyer G, Verheyen FJ (1952) Activation and organization of the central nervous system in amphibians. I. Induction and activation. II. Differentiation and organization. III. Synthesis of a working hypothesis. J Exp Zool 120:1-106

107. Nishioka N, Nagano S, Nakayama R, Kiyonari H, Ijiri T, Taniguchi K, Shawlot W, Hayashizaki Y, Westphal H, Behringer RR, Matsuda Y, Sakoda S, Kondoh H, Sasaki H (2005) Ssdp1 regulates head morphogenesis of mouse embryos by activating the Lim1-Ldb1 complex. Development 132(11):2535-2546. doi:10.1242/dev.01844

108. Nordstrom U, Jessell TM, Edlund T (2002) Progressive induction of caudal neural character by graded Wnt signaling. Nat Neurosci 5(6):525-532. doi:10.1038/nn854

109. Oliver G, Mailhos A, Wehr R, Copeland NG, Jenkins NA, Gruss $P$ (1995) Six3, a murine homologue of the sine oculis gene, demarcates the most anterior border of the developing neural plate and is expressed during eye development. Development 121(12):4045-4055

110. Paek H, Gutin G, Hebert JM (2009) FGF signaling is strictly required to maintain early telencephalic precursor cell survival. Development 136(14):2457-2465. doi:10.1242/dev.032656

111. Paek H, Hwang JY, Zukin RS, Hebert JM (2011) beta-Catenindependent FGF signaling sustains cell survival in the anterior embryonic head by countering Smad4. Dev Cell 20(5):689-699. doi:10.1016/j.devcel.2011.04.010

112. Patthey C, Edlund T, Gunhaga L (2009) Wnt-regulated temporal control of BMP exposure directs the choice between neural plate border and epidermal fate. Development 136(1):73-83. doi:10.1 242/dev.025890

113. Pera EM, Ikeda A, Eivers E, De Robertis EM (2003) Integration of IGF, FGF, and anti-BMP signals via Smad1 phosphorylation in neural induction. Genes Dev 17(24):3023-3028. doi:10.1101/gad.1153603

114. Perea-Gomez A, Vella FD, Shawlot W, Oulad-Abdelghani M, Chazaud C, Meno C, Pfister V, Chen L, Robertson E, Hamada H, Behringer RR, Ang SL (2002) Nodal antagonists in the anterior visceral endoderm prevent the formation of multiple primitive streaks. Dev Cell 3(5):745-756

115. Piccolo S, Agius E, Leyns L, Bhattacharyya S, Grunz H, Bouwmeester T, De Robertis EM (1999) The head inducer Cerberus is a multifunctional antagonist of nodal. BMP and Wnt signals. Nature 397(6721):707-710. doi:10.1038/17820

116. Popperl H, Schmidt C, Wilson V, Hume CR, Dodd J, Krumlauf R, Beddington RS (1997) Misexpression of Cwnt8C in the mouse induces an ectopic embryonic axis and causes a truncation of the anterior neuroectoderm. Development 124(15): 2997-3005

117. Rhinn M, Dierich A, Shawlot W, Behringer RR, Le Meur M, Ang SL (1998) Sequential roles for Otx2 in visceral endoderm and neuroectoderm for forebrain and midbrain induction and specification. Development 125(5):845-856

118. Robb L, Tam PP (2004) Gastrula organiser and embryonic patterning in the mouse. Semin Cell Dev Biol 15(5):543-554. doi:10.1016/j.semcdb.2004.04.005

119. Rodriguez TA, Srinivas S, Clements MP, Smith JC, Beddington RS (2005) Induction and migration of the anterior visceral endoderm is regulated by the extra-embryonic ectoderm. Development 132(11):2513-2520. doi:10.1242/dev.01847

120. Rodriguez-Seguel E, Alarcon P, Gomez-Skarmeta JL (2009) The Xenopus Irx genes are essential for neural patterning and define the border between prethalamus and thalamus through mutual antagonism with the anterior repressors Fezf and Arx. Dev Biol 329(2):258-268. doi:10.1016/j.ydbio.2009.02.028 
121. Rubenstein JL, Martinez S, Shimamura K, Puelles L (1994) The embryonic vertebrate forebrain: the prosomeric model. Science 266(5185):578-580

122. Rubenstein JL, Shimamura K, Martinez S, Puelles L (1998) Regionalization of the prosencephalic neural plate. Annu Rev Neurosci 21:445-477. doi:10.1146/annurev.neuro.21.1.445

123. Sanchez-Arrones L, Ferran JL, Rodriguez-Gallardo L, Puelles L (2009) Incipient forebrain boundaries traced by differential gene expression and fate mapping in the chick neural plate. Dev Biol 335(1):43-65. doi:10.1016/j.ydbio.2009.08.012

124. Saude L, Woolley K, Martin P, Driever W, Stemple DL (2000) Axis-inducing activities and cell fates of the zebrafish organizer. Development 127(16):3407-3417

125. Scholpp S, Wolf O, Brand M, LumsdenA (2006) Hedgehog signalling from the zona limitans intrathalamica orchestrates patterning of the zebrafish diencephalon. Development 133(5):855-864. doi: 10.1242/dev.02248

126. Shawlot W, Behringer RR (1995) Requirement for Lim 1 in head-organizer function. Nature 374(6521):425-430. doi: $10.1038 / 374425 \mathrm{a} 0$

127. Shawlot W, Wakamiya M, Kwan KM, Kania A, Jessell TM, Behringer RR (1999) Lim1 is required in both primitive streakderived tissues and visceral endoderm for head formation in the mouse. Development 126(22):4925-4932

128. Shimamura K, Hartigan DJ, Martinez S, Puelles L, Rubenstein JL (1995) Longitudinal organization of the anterior neural plate and neural tube. Development 121(12):3923-3933

129. Shimamura K, Martinez S, Puelles L, Rubenstein JL (1997) Patterns of gene expression in the neural plate and neural tube subdivide the embryonic forebrain into transverse and longitudinal domains. Dev Neurosci 19(1):88-96

130. Shimamura K, Rubenstein JL (1997) Inductive interactions direct early regionalization of the mouse forebrain. Development 124(14):2709-2718

131. Smukler SR, Runciman SB, Xu S, van der Kooy D (2006) Embryonic stem cells assume a primitive neural stem cell fate in the absence of extrinsic influences. J Cell Biol 172(1):79-90. doi $: 10.1083 /$ jcb. 200508085

132. Snippert HJ, Clevers H (2011) Tracking adult stem cells. EMBO Rep 12(2):113-122. doi:10.1038/embor.2010.216

133. Sousa VH, Fishell G (2010) Sonic hedgehog functions through dynamic changes in temporal competence in the developing forebrain. Curr Opin Genet Dev 20(4):391-399. doi:10.1016/j.gde.2010.04.008

134. Spemann H, Mangold H (1924) Induction of embryonic primordia by implantation of organizers from a different species. Roux's Arch Entw Mech 100:599-638

135. Srinivas $S$ (2006) The anterior visceral endoderm-turning heads. Genesis 44(11):565-572. doi:10.1002/dvg.20249

136. Stern CD, Downs KM (2012) The hypoblast (visceral endoderm): an evo-devo perspective. Development 139(6):10591069. doi:10.1242/dev.070730

137. Sterneckert J, Stehling M, Bernemann C, Arauzo-Bravo MJ, Greber B, Gentile L, Ortmeier C, Sinn M, Wu G, Ruau D, Zenke M, Brintrup R, Klein DC, Ko K, Scholer HR (2010) Neural induction intermediates exhibit distinct roles of Fgf signaling. Stem Cells 28(10):1772-1781. doi:10.1002/ stem.498

138. Storey KG, Crossley JM, De Robertis EM, Norris WE, Stern CD (1992) Neural induction and regionalisation in the chick embryo. Development 114(3):729-741

139. Storm EE, Garel S, Borello U, Hebert JM, Martinez S, McConnell SK, Martin GR, Rubenstein JL (2006) Dose-dependent functions of Fgf8 in regulating telencephalic patterning centers. Development 133(9):1831-1844. doi:10.1242/dev.02324
140. Streit A, Berliner AJ, Papanayotou C, Sirulnik A, Stern CD (2000) Initiation of neural induction by FGF signalling before gastrulation. Nature 406(6791):74-78. doi:10.1038/35017617

141. Sulik K, Dehart DB, Iangaki T, Carson JL, Vrablic T, Gesteland K, Schoenwolf GC (1994) Morphogenesis of the murine node and notochordal plate. Dev Dyn 201(3):260-278. doi:10.1002/ aja.1002010309

142. Surmacz B, Fox H, Gutteridge A, Lubitz S, Whiting P (2012) Directing differentiation of human embryonic stem cells toward anterior neural ectoderm using small molecules. Stem Cells 30(9):1875-1884. doi:10.1002/stem.1166

143. Takaoka K, Yamamoto M, Hamada H (2007) Origin of body axes in the mouse embryo. Curr Opin Genet Dev 17(4):344-350. doi:10.1016/j.gde.2007.06.001

144. Takaoka K, Yamamoto M, Hamada H (2011) Origin and role of distal visceral endoderm, a group of cells that determines anterior-posterior polarity of the mouse embryo. Nat Cell Biol 13(7):743-752. doi:10.1038/ncb2251

145. Tam PP, Steiner KA (1999) Anterior patterning by synergistic activity of the early gastrula organizer and the anterior germ layer tissues of the mouse embryo. Development 126(22):5171-5179

146. Thomas P, Beddington R (1996) Anterior primitive endoderm may be responsible for patterning the anterior neural plate in the mouse embryo. Curr Biol 6(11):1487-1496

147. Thomas PQ, Brown A, Beddington RS (1998) Hex: a homeobox gene revealing peri-implantation asymmetry in the mouse embryo and an early transient marker of endothelial cell precursors. Development 125(1):85-94

148. Tian E, Kimura C, Takeda N, Aizawa S, Matsuo I (2002) Otx2 is required to respond to signals from anterior neural ridge for forebrain specification. Dev Biol 242(2):204-223. doi:10.1006/ dbio.2001.0531

149. Trichas G, Joyce B, Crompton LA, Wilkins V, Clements M, Tada M, Rodriguez TA, Srinivas S (2011) Nodal dependent differential localisation of dishevelled-2 demarcates regions of differing cell behaviour in the visceral endoderm. PLoS Biol 9(2):e1001019. doi:10.1371/journal.pbio.1001019

150. Trichas G, Smith AM, White N, Wilkins V, Watanabe T, Moore A, Joyce B, Sugnaseelan J, Rodriguez TA, Kay D, Baker RE, Maini PK, Srinivas S (2012) Multi-cellular rosettes in the mouse visceral endoderm facilitate the ordered migration of anterior visceral endoderm cells. PLoS Biol 10(2):e1001256. doi:10.1371/journal.pbio.1001256

151. Varlet I, Collignon J, Robertson EJ (1997) Nodal expression in the primitive endoderm is required for specification of the anterior axis during mouse gastrulation. Development 124(5):1033-1044

152. Villegas SN, Canham M, Brickman JM (2010) FGF signalling as a mediator of lineage transitions-evidence from embryonic stem cell differentiation. J Cell Biochem 110(1):10-20. doi: $10.1002 / j \mathrm{cb} .22536$

153. Waddington $\mathrm{CH}$ (1933) Induction by the primitive streak and its derivatives in the chick. J Exp Biol 10:38-46

154. Wills AE, Choi VM, Bennett MJ, Khokha MK, Harland RM (2010) BMP antagonists and FGF signaling contribute to different domains of the neural plate in Xenopus. Dev Biol 337(2):335-350. doi:10.1016/j.ydbio.2009.11.008

155. Wilson PA, Hemmati-Brivanlou A (1995) Induction of epidermis and inhibition of neural fate by Bmp-4. Nature 376(6538):331333. doi:10.1038/376331a0

156. Wilson SI, Rydstrom A, Trimborn T, Willert K, Nusse R, Jessell TM, Edlund T (2001) The status of Wnt signalling regulates neural and epidermal fates in the chick embryo. Nature 411(6835): 325-330. doi:10.1038/35077115

157. Wilson SW, Houart C (2004) Early steps in the development of the forebrain. Dev Cell 6(2):167-181 
158. Withington S, Beddington R, Cooke J (2001) Foregut endoderm is required at head process stages for anteriormost neural patterning in chick. Development 128(3):309-320

159. Woo K, Fraser SE (1995) Order and coherence in the fate map of the zebrafish nervous system. Development 121(8):2595-2609

160. Wu CI, Hoffman JA, Shy BR, Ford EM, Fuchs E, Nguyen H, Merrill BJ (2012) Function of Wnt/beta-catenin in counteracting Tcf3 repression through the Tcf3-beta-catenin interaction. Development 139(12):2118-2129. doi:10.1242/dev.076067

161. Yamamoto M, Saijoh Y, Perea-Gomez A, Shawlot W, Behringer RR, Ang SL, Hamada H, Meno C (2004) Nodal antagonists regulate formation of the anteroposterior axis of the mouse embryo. Nature 428(6981):387-392. doi:10.1038/nature02418

162. Yang YP, Anderson RM, Klingensmith J (2010) BMP antagonism protects Nodal signaling in the gastrula to promote the tissue interactions underlying mammalian forebrain and craniofacial patterning. Hum Mol Genet 19(15):3030-3042. doi:10.1093/h $\mathrm{mg} / \mathrm{ddq} 208$

163. Yang YP, Klingensmith J (2006) Roles of organizer factors and BMP antagonism in mammalian forebrain establishment. Dev Biol 296(2):458-475. doi:10.1016/j.ydbio.2006.06.014 